\title{
Workshop Penyusunan Proposal Penelitian Tindakan Kelas (PTK) Bagi Guru Di MTSN 1 Alas
}

\author{
Sanapiah $^{1}$, I Ketut Sukarma ${ }^{2}$, Eliska Juliangkary ${ }^{3}$, Sri yuliyanti ${ }^{4}$, Pujilestari $^{5}$, Ade Kurniawan ${ }^{6}$, \\ Ahmad Muzaki ${ }^{7}$, Nurdin ${ }^{8}$ \\ 1,2,3,4,5,6,7 Dosen Program Studi Pendidikan Matematika, UNDIKMA Mataram \\ ${ }^{8}$ Dosen Program Studi Bahasa Indonesia, Universitass Terbuka \\ Email: sanapiah27@yahoo.com
}

\begin{abstract}
Abstrak: Guru dan Dosen bahwa guru wajib memiliki empat kompetensi. Keempat kompetensi itu adalah kompetensi pedagogik, kompetensi profesional, kompetensi sosial, dan kompetensi kepribadian. Sebagai pendidik yang memiliki kompetensi profesional, Salah satu dari komponen pengembangan profesi itu adalah laporan penelitian tindakan kelas (PTK). Workshop penyusunan proposal penelitian tindakan kelas (PTK) dilakukan pada guru MTsN 1 Alas, Kecamatan Alas, Kabupaten Sumbawa NTB. Tujuan Workshop ini dilakukan (1) menyampaikan konsep dasar dan pengertian penelitian tindakan kelas; (2) mengungkapkan karakteristik penelitian tindakan kelas; (3) menyampaikan prinsip-prinsip penelitian tindakan kelas; (4) mengungkapkan tujuan dan manfaat penelitian tindakan kelas; (5) mendeskripsikan prosedur pelaksanaan penelitian tindakan kelas; (6) mengidentifikasi masalah yang dapat diteliti; dan (7) menyusun rencana (prat dari proposal) penelitian tindakan kelas (PTK). Metode pelaksanaan PKM ini terdiri dari tahapan (1) pemberian materi pelatihan, (2) Penyusunan proposal Penelitian Tindakan Kelas (PTK) oleh peserta; 3) Telaah proposal Penelitian Tindakan Kelas (PTK).
\end{abstract}

Kata kunci: Roposal, Penelitian Tindakan Kelas

\section{PENDAHULUAN}

Paradigma tugas guru mulai berubah. Undang-Undang Republik Indonesia Nomor 2 Tahun 1989 tentang Sistem Pendidikan Nasional menyatakan tugas guru sebagai pengajar. Hal itu berubah di dalam Undang-undang Republik Indonesia Nomor 20 Tahun 2003 yakni tugas guru mendidik. Untuk melaksanakan tugas mendidik itu ditegaskan oleh Undang-undang Nomor 14 tahun 2005 tentang Guru dan Dosen bahwa guru wajib memiliki empat kompetensi. Keempat kompetensi itu adalah kompetensi pedagogik, kompetensi profesional, kompetensi sosial, dan kompetensi kepribadian.

Sebagai pendidik yang memiliki kompetensi profesional, guru membuktikannya dengan sertifikat. Sertifikat itu didapat melalui kegiatan sertifikasi guru. Peraturan Menteri Pendidikan Nasional Nomor 18 Tahun 2006 tentang Sertifikasi Guru menyatakan bawa guru harus mengumpulkan dokumen untuk pengisi portofolio. Salah satu dari komponen portofolio itu adalah pengembangan profesi. Salah satu dari komponen pengembangan profesi itu adalah laporan penelitian tindakan kelas.

Berdasarkan hal itu, penelitian tindakan kelas (PTK) menjadi penting bagi guru. Ada semacam kemutlakan bahwa guru harus melakukan kegiatan ini. Bahan sederhana ini merupakan sumbangan kepada sejawat guru untuk melakukan PTK. Panduan sederhana bagi guru untuk dapat melakukan penelitian tindakan kelas. Dengan membaca bahan ini, kesulitankesulitan yang selama ini dialami guru ketika melakukan PTK, mudah-mudahan teratasi.

Bahan sajian ini ditulis dalam dua bagian atau dua garis besar isi. Bagian pertama membahas konsep-konsep dasar penelitian tindakan kelas. Bagian ini dimaksudkan untuk mengantarkan pembaca ke tingkat pemahaman konsep menuju penerapan atau aplikasi. Konsep-konsep disajikan secara sederhana, secara lugas, dan diiringi dengan contoh-contoh kongkret. Dengan penyajian dan contoh itu memungkinkan guru dapat memahami konsep dengan mudah. Selain itu, bagian ini juga 
disajikan secara bervariasi dan menghimpun sejumlah pendapat pakar tentang konsep penelitian tindakan kelas. Pendapat-pendapat itu ditampilkan untuk meletakkan pemahaman dasar tentang konsep penelitian tindakan kelas. Dengan demikian pembaca akan dapat membuat konklusi dari sajian ini.

Bagian kedua adalah bagian penerapan. Bagian ini membukakan jalan bagi sejawat guru untuk melangkah menuju kegiatan PTK. Kegiatan diawali dengan menyusun perencanaan atau proposal penelitian tindakan kelas. Dari mana dan bagaimana memulai kegiatan penelitian tindakan kelas, dijelaskan pada bagian ini. Selanjutnya dijelaskan dalam bentuk pelatihan-pelatihan praktis secara bertahap dan berkesinambungan. Guru dipandu melangkah secara bertahap, selangkah demi selangkah, hingga sampai ke pelaksanaan tindakan dan penyusunan laporan.

Dengan dua garis besar sajian ini, diharapkan guru bukan saja memahami konsep dan teknik penelitian tindakan kelas, tetapi lebih dari itu, yakni guru akrab dan terbiasa melakukan kegiatan ini. Tentu saja hal ini kembali berpulang kepada sejawat guru dalam aplikasinya. PTK atau Penelitian Tindakan Kelas merupakan karya tulis ilmiah guru untuk perbaikan mutu PBM. Suharsimi Arikunto (2006) menjelaskan frasa penelitian tindakan kelas dari unsur kata pembentuknya, yakni penelitian, tindakan, dan kelas. Penelitian mengacu pada suatu kegiatan mencermati suatu objek dengan menggunakan cara atau aturan metodologi tertentu untuk memperoleh data atau informasi yang bermanfaat untuk meningkatkan mutu suatu hal yang menarik minat dan penting bagi peneliti. Tindakan mengacu pada suatu gerak kegiatan yang sengaja dilakukan dengan tujuan tertentu. Dalam penelitian tindakan kelas tindakan itu berbentuk rangkaian siklus kegiatan untuk siswa. Penelitian Tindakan Kelas merupakan penelitian yang lebih baik dilakukan oleh guru sebagai pelaksana program KBM di kelas. Sehingga, guru diharuskan menguasai keterampilan-keterampilan dalam Penelitian Tindakan Kelas (PTK).
Dengan menanggapi permasalah ini, maka diperlukan workshop lebih lanjut tentang "Workshop Penyusunan Penulisan Proposal Penelitian Tindakan Kelas (PTK) Bagi Guru di MTsN 1 Alas" Hal ini diperlukan untuk dapat menumbuhkan semangat para guru untuk terus mengasah keterampilan menulis.

\section{METODE PELAKSANAAN \\ Kerangka Pemecahan Masalah}

Berikut metode yang dilakukan dalam workshop penyusunan proposal Penelitian Tindakan Kelas (PTK):

1. Metode Pelaksanaan : ceramah bervariasi, praktek, diskusi dan Tanya jawab.

2. Materi Pelatihan:

a. Menyampaikan konsep dasar dan pengertian penelitian tindakan kelas.

b. Mengungkapkan karakteristik penelitian tindakan kelas

c. Menyampaikan prinsip-prinsip penelitian tindakan kelas.

d. Mengungkapkan tujuan dan manfaat penelitian tindakan kelas.

e. Mendeskripsikan prosedur pelaksanaan penelitian tindakan kelas.

f. Mengidentifikasi masalah yang dapat diteliti.

g. Menyusun rencana (prat dari proposal) penelitian tindakan kelas (PTK)

3. Penyusunan proposal Penelitian Tindakan Kelas (PTK) oleh peserta

4. Telaah proposal Penelitian Tindakan Kelas (PTK)

Dalam rangka pemecahan masalah dapat digambarkan pada gambar 1 . 




Gambar 1. Kerangka Pemecahan Masalah

\section{HASIL DAN PEMBAHASAN}

Kegiatan PKM ini telah dilaksanakan pada hari Sabtu tanggal 30 Januari 2016 yang bertempat di SMAN 1 Alas dengan jumlah peserta yang hadir 54 orang dari 80 undangan yang berasal dari beberapa SMP/MTs dan SMA/SMK di kecamatan Alas Barat, Alas, Buer dan Utan. Kegiatan PKM ini dimulai pada pukul 08.00 hingga pukul 17.00 yang dibuka langsung oleh kepala sekolah SMAN 1 Alas Bapak Purwanto S.Pd. Hasil pelaksanaan kegiatan PKM ini dirasakan oleh TIM pengabdian maupun peserta pelatihan yang sangat memuaskan. Dengan indikator kedatangan peserta hampir $70 \%$ dari 80 orang undangan dan antusias peserta, hingga sore hari kegiatan dilaksanakan tidak ada satupun peserta yang ingin meninggalkan tempat duduk. Hasil diskusi dan tanya jawab yang dilakukan berhasil baik dan sangat maksimal. Para peserta Workshop umumya terdiri dari guru-guru senior yang pangkat dan golongannya masih IIIA ataupun IVA yang ingin mengubah kenaikan pangkat dan golongannya.
Kegiatan PKM ini dilakasanakan dengan Metode ceramah dan tanya jawab, serta demontrasi dan praktek. Dari hasil diskusi terungkap bahwa rata-rata para pangkat dan golongan peserta staknasi lebih dari 10 tahun. Ini artinya bahwa banyak sekali jumlah rupiah yang tidak diambil oleh para guru dari uang tunjang yang seharusnya menjadi haknya. Hal ini disebabkan oleh belum mampunya para guru dalam menghasilkan karya tulis ilmiah baik berupa laporan PTK, artikel ataupun bahan ajar/Modul. Kenyataan ini terungkap pada sesi tanya jawab, dimana hampir semua peserta mengajukan pertanyaan dan menyampaikan keluh kesahnya yang dihadapi selama ini dalam menyusun satu judul PTK saja. Hal ini berarti bahwa kegiatan workshop ini berhasil dilakasanakan dengan mendapat dukungan dan respon yang sangat luar biasa dari para peserta.

Kegiatan ini mampu memberikan pencerahan dan motivasi bagi peserta workshop, tentang kegalauan mereka dalam menyusun proposal PTK dan publikasinya. Dari materi yang disampaikan oleh pemateri (Prof.Ir.Suhubdy Yasin,Ph.D dan Dr Gunawan, M.Pd) mampu membuat para peserta terkesan, bahwa untuk menyusun proposal PTK itu gampang, hanya saja dibutuhkan kemamuan yang keras bagi guru untuk meluangkan sedikit waktu untuk banyak membaca. Para pemateri menegaskan bahwa ada banyak ide untuk membuat proposal PTK, Namun pikiran guru masih terbelenggu dengan rasa takutnya. Hal ini juga terungkap ketika kegiatan Tanya jawab berlangsung. Antusias yang yang diperlihatkan oleh guru nampak pada kegiatan diskusi dan tanya jawab dengan tidak adanya peserta yang keluar masuk maupun diskusi dengan teman yang lain dalam ruang workshop.

Namun keberhasilan memberikan motivasi dan pengetahuan bagi para peserta workshop ini belumlah cukup, karena para guru harus dibimbing langsung untuk menghasilkan draf proposal PTK ataupun draf artikel. Pengalaman kami dalam melaksanakan kegiatan yang serupa, bahwa guru sangat antusian sekali mengikuti kegiatan workshop tetapi belum mampu menghasilkan laporan PTK ataupun 
artikel yang dimaksud tanpa pembimbingan langsung setelah kegiatan selesai. Untuk itu, kegiatan ini perlu ada tindak lanjutnya dengang melakukan pendamping secara langsung bagi guru-guru dalam membuat proposal PTK. Padahal untuk membuat proposal PTK merupakan hal yang sangat mudah bagi guru, karena permasalahan yang muncul dari kegiatan pengajaran yang dilaksanakan sehari-hari dapat dimanfaatkan untuk diangkat dalam sebuah penelitian.

Adapun Langkah-langkahnya yang tela dilaksanakan dalam kegiatan workshop adalah sebagai berikut:

a. Memberikan ceramah tentang

pentingnya melakukan Penelitian

Tindakan Kelas (PTK).

b. Memberikan ceramah tentang manfaat melakukan Penelitian Tindakan Kelas (PTK).

c. Mendemonstrasikan bagaimana langkah-langkah pembuatan proposal Penelitian Tindakan Kelas (PTK).

Materi pertama yang diangkat oleh pemateri adalah tentang pengetahuan dan motivasi dalam menyususn proposal PTK dan publikasi karya ilmiah. Diawal pembahasan materi ini, belum banyak peserta terfokus dan antusias mendengarkan pemateri. Hal ini terlihar dari banyaknya peserta yang masih sibuk dengan urusan sendiri walaupun sudah berada pada ruang workshop. Dengan melihat keadaan tersebut, pemateri tidak melanjutkan penyampaian materinya, namun dialihkan dengan tanya jawab untuk memfokuskan peserta pada materi yang sedang di sampaikan. Dari hasil Tanya jawab terungkap, bahwa pengetahuan peserta tentang penyususna PTK dan publikasi masih sangat terbatas. Hal itulah yang menyebabkan para peserta tidak beranjak untuk mengurus kenaikan pangkat dan golongannya, karena terbentur dengan belum adanya laporan PTK yang sudah dilaksanakan ataupun artikel yang telah terbulikasi.
Situasi pelaksanaan diskusi dan tanya jawab yang dilakukan oleh pemateri ini nampak hidup demikian juga waktu tutorial dapat berjalan dengan baik. Karena para guru merasa perlu untuk mereka dalam pengusulan kenaikan pangkat dan golongan serta sertifikasi. Kegiatan seperti ini belum pernah dilakukan, namun pernah diusulkan kepada dinas terkait tetapi tidak ada tanggapan. Kegiatan ini terlaksana berkat ada ide dari salah seorang alumni SMAN 1 Alas sebagai bentuk pengabdiannya bagi guru-guru untuk membantu memberikan arahan dan motivasi dalam menghasilkan laporan PTK dan artikel yang terbublikasi.

Kegiatan pengabdian kepada masyarakat sangat bermanfaat bagi guru-guru untuk meningkatkan dan membekali kreativitas guru dalam melakukan Penelitian Tindakan Kelas (PTK). Melalui kegiatan ini diharapkan guruguru mampu memperbaiki kualitas pembelajaran salah satunya dengan melakukan Penelitian Tindakan Kelas (PTK). Evaluasi dari kegiatan pengabdian kepada masyarakat ini dilaksanakan diakhir kegiatan dengan cara meminta kepada para peserta pelatihan untuk mengungkapkan aspek positif dan negatif yang dirasakan setelah mengikuti kegiatan pelatihan ini.

\section{KESIMPULAN DAN SARAN}

Pelaksanaan kegiatan PKM di Kabupaten Sumbawa khususnya di Kecamatan alas barat, Alas, Buer, dan Utan sangat dirasakan manfaat oleh para peserta workshop dan sekolah pihak penyelenggara yaitu SMAN 1 Alas dan juga oleh TIM pengabdi yang hasilnya sangat memuaskan. Dengan indikator kehadiran peserta dan antusias peserta pelatihan sangat baik. Hasil dari pelatihan pembuatan karya tulis ilmiah berujud makalah, diktat dan PTK sudah cukup baik. Suasana belajar dan tutorial cukup bagus. Hampir semua peserta mengikuti dari awal sampai akhir. Para pejabat terkait sangat mendukung pelaksanaan pengabdian masyarakat yang dilaksanakan oleh TIM pengabdian IKIP Mataram, dan mengharapkan adanya tindak lanjut dari kegiatan yang serupa 
untuk dapat menghasilkan karya ilmiah baik berupa laporan PTK, artikel, maupun bahan ajar/modul.

Agar peserta pelatihan mengembangkan terus pembuatan karya tulis ilmiah yang menjadi kewajiban guru dalam meningkatkan profesionalismenya yang sekaligus akan meningkatkan wawasannya sebagai pendidik. Para pejabat pendidikan di kabupaten Sumbawa harus memberikan dukung untuk dapat terlaksananya kegiatan yang serupa agar memotivasi para guru supaya mau menulis karya tulis ilmiah untuk kemajuan para guru dan peserta didiknya serta nama baik daerahnya.

\section{DAFTAR PUSTAKA}

Arikunto, S. 2006. Prosedur Penelitian: Suatu Pendekatan Praktik. Edisi Revisi VI. Cetakan ke-13. Jakarta: PT Rineka Cipta. Depdiknas. 2004. Pedoman Penyusunan Usulan Penelitian Tindakan Kelas (Classroom Action Research). Jakarta: Direktorat Jenderal Pendidikan Tinggi, Depdiknas.

Eggen, P \& Kauchak, D. 2012. Strategi dan model pembelajaran: Mengajarkan content dan keterampilan berpikir edisi keenam (diterjemahkan oleh Satrio Wahono). Pearson Education, Inc.

Latief, Mohammad Adnan, 2010. Tanya Jawab Metode Penelitian Pembelajaran Bahasa. Malang: UM Press

Mengembangkan Profesionalisme Guru. Bandung: Raja Grafindo Persada

Rusman. 2011. Seri Manajemaen Sekolah Bermutu. Model-Model Pembelajaran Sugiyono, 2011. Metode penelitian kuantitatif dan kualitatif dan $\mathrm{R}$ dan $\mathrm{D}$. Bandung: Alfabeta 